Asst. Prof. Dr. ilknur Kahriman'

Karadeniz Technical University, Trabzon

Asst. Prof. Dr. Mehmet Kanak ${ }^{2}$

Cumhuriyet University, Sivas

Turkey
Original scientific paper

UDK: 37.013 .77

DOI: $10.17810 / 2015.79$

\title{
THE EXAMINATION OF THE KNOWLEDGE, ATTITUDES AND PRACTICES OF EXPECTANT MOTHERS TOWARDS SIBLING JEALOUSY AND THE JEALOUSY BEHAVIORS IN THEIR CHILDREN
}

\begin{abstract}
This research is a quantitative study carried out to determine the knowledge, attitudes and practices of expectant mothers towards sibling jealousy and the jealousy behaviors observed in their children using a relational search model. The study group consisted of 390 hospitalized mothers in the Gynecology Clinic of a University Hospital between August 2015 and August 2016. The data were collected using surveys developed by the researchers after the required permissions were obtained according to the ethical guidelines. The basic data such as the participants' knowledge about sibling jealousy, the methods they used to avoid it and their demographic information were presented with frequency and percentage tables. In order to determine the relationship between the mean scores of current jealousy behaviors of the children and those after learning that they would have a new sibling, the $t$ test, one of the parametric tests, was applied because of the normal distribution of the data obtained after the assumptions of normality were examined. As a result of the statistical procedures, almost all of the mothers (94.6\%) said to have informed the big sibling about their pregnancy, most of the participants (58.5\%) had information to avoid jealousy among the siblings, more than half of them (52.3\%) did not get any information about childrearing before, and those who did mostly got it from television/ the internet. In our study, it was observed that sibling jealousy is more common in siblings with a higher average age and in girls. Besides, it is more common among the children whose mothers aged 35 years and under and high school graduates and the sibling jealousy behaviors after the baby came home were found to be significantly lower than those after learning that they would have a new sibling.
\end{abstract}

Key Words: Child, sibling jealousy, jealousy behavior, mother.

\section{INTRODUCTION}

Siblings are an indispensable element of children's social life. They may sometimes become playmates, care givers, teachers, and sometimes a problematic part of each other's lives (Sipal, et al., 2012). For most people, sibling relationships involve a long period of time, beginning with the birth of a sibling and ending with the death of one of them (Noller, 2005). The sibling relationship is one of the earliest contexts in which children learn to participate in

\footnotetext{
1ilknurkahriman@hotmail.com

2mkanak@cumhuriyet.edu.tr
} 
emotional reactions of their own and others regarding competition and jealousy reactions (Miller et al., 2000).

Any change in life brings stress. The birth of a sibling can also be a stressful life event for young children and their families (Volling et al., 2014). People experience many good or bad feelings throughout their lives. Jealousy is one of these emotions and it is very complicated (Miller, et al., 2000).

Jealousy is considered as an unpleasant social feeling. By definition, it occurs when people are in a situation where the possibility of losing a valuable relation to an opponent is a threat (Bauminger et al., 2008). The main reason for a child's jealousy towards his / her sibling is the perception that a parent (loved one) shows different and more favorable interest to another sibling (Thampson and Halberstadt, 2008). Parents of siblings usually have to deal with the debates between them. Sibling jealousy is a very common case among children and a very important issue in the family because siblings spend a considerable part of their time together and can spend this time fighting when there is jealousy. This situation is very tiring for parents, too (Thompson and Halberstadt, 2008).

There are three relationships in the jealousy system: (1) the relationship between the jealous individual and the loved one, (2) the relationship between the loved one and the opponent, and (3) the relationship between the jealous individual and the opponent. In sibling jealousy, sibling is the opponent and the loved one is the parent (Miller et al., 2000; Thampson and Halberstadt, 2008). Sibling jealousy is the competition between the siblings to draw the attention of their parents (Thompson, 2004).

It is important to note how children react to their parents' initial interaction with their new siblings. Initial responses provide an indication about whether children are accepting new babies and may be a good indicator of how children are adapting to their siblings (Volling et al., 2014). For example, a child may consider a newborn baby as a threat to the mother-child relationship, may be worried and interferes with mother-baby interaction, or considers her mother inaccessible, which gives the child a feeling of sadness and withdrawal from interaction (Volling et al., 2014). Those who are less preferred than their siblings may have a more insecure identity. Moreover, individuals who are jealous of their siblings can see others as opponents and potential enemies rather than supporters (Rauer and Volling, 2007). Mothers stated that first-born children exhibit demanding and maladaptive behaviors that intentionally cause stress on them three weeks after the birth of their second child, because the first child is both joyful and jealous of her/his sibling's birth (Volling et al., 2014).

Pike, Coldwell and Dunn (2005) suggested that positiveness is also evident in sibling relationships as well as conflict as an important link in children's adjustment, and it is reflected in pro-social behavior as well as total behavior problems. Positive relationship with the sibling is a great social support for the person and protects him/her from psychological risk factors.

Parental attitudes have also a great effect on sibling jealousy. It can fuel the jealousy between the siblings as well as improving the relationship between them (Alper, 2002).

We need to prepare the child for a new sibling. The first meeting of the child with the mother should be when the mother feels comfortable. If the child sees the mother as sick and exhausted, s/he can see the baby as responsible and blame him/her. The first meeting with the 
baby should be in the bed of the baby if possible, and a gift placed next to the bed will make the child happy and relaxed (Donat Bacioglu, 2017).

When a new baby is included in the family, to avoid sibling jealousy, the parents should try to present the same life to the first child as they used to do. That is, the parents and the first child should continue to go on weekend trips together, spend time together without the baby, and make less change in their lives (Gumus, 2016). The mother should be interested in the baby and should not stop dealing with the other child at the same time. For example, even if she is breastfeeding the baby, she should also play with the other child with her hand (Donat Bacioglu, 2017).

The moment when the child is informed about his/her sibling's coming should be carried out as plainly and modestly as possible, away from a ceremony. For example, the child can be given brief and clear information; for example, a new baby is joining our family. The child must be separated from the bed and the room of the parents before the baby arrives. If a child is to be sent to a nursery or caregiver, it must be done before the birth because after the birth of the baby, sending the child away from the room or house so that $\mathrm{s} / \mathrm{he}$ will not be jealous of the baby will cause the child to feel thrown out of the house (Yorukoglu, 2006; Donat Bacioglu, 2017).

Comparisons between siblings should never be made because each one of them has different talents and interests. Cooperation in the family should be given importance. Individual responsibilities should be given according to the interests and abilities of the children. In the evaluation, it is the effort that should be paid attention to. The child must be given the message that $\mathrm{s} /$ he is not a bad boy/girl because of jealousy. Otherwise the child will feel guilty. In short, the position of the child before the birth of baby should be preserved after the birth. In this way the child will not lose his/her self-confidence and will be able to keep his/her relationship with the baby more balanced (Yavuzer, 2010). It would not be appropriate for the mother or a family member to love the baby in a flashy manner near the child (Yorukoglu, 2006). Shopping for the newborn should not be exaggerated and disturbing for the child (Donat Bacioglu, 2017).

The children seem to have been pushed to the background whereas they are the focus of interest and love at home until that day (Yavuzer, 2010). Now they have to share the love and care of his/her parents and other relatives with their new sibling. They think that they are not loved and become totally distant from their mothers, become introverted, start not to eat and lose weight. They try to draw the attention to themselves, pretending to have nightmares and need to pee. A regression to the previous developmental stage may be seen with behaviors such as bedwetting and finger sucking. They become overly nervous both during the day and night. They have an uneasy appearance, difficulty in calming down, and sometimes they can be angry with the people around them. They can harm their bodies or the objects around them (Yavuzer, 2010). In their study examining the jealousy between twins and the siblings with age gap, Şipal et al., found that twin siblings were reactive only when their mothers were disinterested or when there was decreased interest in their mothers, and that they did not exhibit jealousy behaviors in terms of adaptation and competition among the other siblings (Şipal et al., 2012). Telling the children that their siblings will always support them and will be their best friends in life will also strengthen the positive attitudes of the children in this direction (Kildan, 2004 qtd. Ozyurek, 2015). 
In research it was seen that the families were inadequate to solve the conflicts between the siblings and passed over the problems because the older sibling end up changing his/her tune (Kilicarslan 2001). In Yavuzer's study (2007) it was observed that with the birth of a new sibling, mothers spent less time and played less with the older child. This approach may lead to older children developing emotions such as anger and resentment towards the baby, or directing these feelings to the mother and father (Yavuzer, 2007). If the causes of jealousy are not removed, the peace of the family will be disturbed and children's personality development will be affected (Yigen, 2005). Jealousy between siblings cannot be completely removed but can be alleviated. Therefore, necessary precautions should be taken before and after the birth of a baby (Yavuzer, 2010).

The purpose of this study is to determine the knowledge, attitudes and practices of expectant mothers about sibling jealousy and the jealous behaviors observed in their children. Considering the fact that there are a limited number of national publications on sibling jealousy, the findings of our study are expected to guide professionals working with children and health professionals.

\section{METHOD}

In this part of the study, the design of the study, the study group, the data collection tools and the analysis of the data are included.

\section{Research Design}

In this study the relational search model, one of the quantitative screening models, which obtains information by comparison was used. It is a type of a research model which aims at revealing the relationship between two or more variables or the degree of the relationship (Fraenkel, et al., 2006).

\section{Study group}

The study group in this study comprised of 390 mothers hospitalized in the Gynecology Clinic of a University Hospital between August 2015 and August 2016. When the study group was identified, the primary criterion was to be a volunteer. To determine the study group, the criteria sampling method, one of the purposeful sampling methods, was used. The criterion sampling method is used when all situations that meet a pre-determined set of criteria are studied. Criteria can be created by the researcher or a previously prepared criteria list can be used (Yildirim and Simsek, 2016). In this study, since the focus was on the mothers who would give birth and had at least one more child, our criteria was determined in this direction.

\section{Data Collection Tools}

The data collection was carried out after the required permissions were obtained according to the ethical guidelines (permission numbered 48814514-200 was obtained from the relevant institution on 10. 06. 2008). In the collection of the data, a survey developed by the researchers was used. 


\section{Data Analysis}

The mothers who participated in the study group were given brief information before the application and then the data collection tools were applied voluntarily. The required assumptions for the analysis were examined after the data were entered into SPSS 22.0 package program in the computer environment. The basic data such as the knowledge of the participants about sibling jealousy, the methods they used to avoid jealousy and the demographic information were presented with frequency and percentage tables. In order to determine the relationship between the mean scores of current jealousy behaviors of the children and those after learning that they would have a new sibling, the t test, one of the parametric tests, was applied because of the normal distribution of the data obtained after the assumptions of normality were examined.

\section{RESULTS}

Table 1. Socio-demographic characteristics of the expectant mothers and their status of informing their children about their pregnancy

\begin{tabular}{|c|c|c|}
\hline \multirow{2}{*}{$\begin{array}{l}\text { Average age of the father (Mean } \pm \text { SS) } \\
\text { The occupation of the mother }\end{array}$} & \multicolumn{2}{|c|}{$36.35 \pm 5.67$} \\
\hline & 294 & 75.4 \\
\hline Housewife & 33 & 8.5 \\
\hline Worker & 53 & 13.6 \\
\hline Civil Servant & 10 & 2.5 \\
\hline \multicolumn{3}{|l|}{ Self-employed } \\
\hline Educational status of the mother & 164 & 42.1 \\
\hline Primary school and below & 57 & 14.6 \\
\hline Secondary School & 120 & 30.8 \\
\hline High school & 49 & 12.6 \\
\hline \multicolumn{3}{|l|}{ University } \\
\hline $\begin{array}{l}\text { Status of informing the child about the new } \\
\text { sibling }\end{array}$ & 369 & 94.6 \\
\hline Yes & 21 & 5.4 \\
\hline \multicolumn{3}{|l|}{ No } \\
\hline $\begin{array}{l}\text { The time when the mother started to prepare } \\
\text { the child for the new sibling }\end{array}$ & 232 & 59.5 \\
\hline After the confirmation of their pregnancy & 67 & 17.2 \\
\hline In the last months of the pregnancy & 51 & 13.1 \\
\hline In the course of planning to get pregnant & 40 & 10.3 \\
\hline \multicolumn{3}{|l|}{ Not yet } \\
\hline $\begin{array}{l}\text { The status of knowing what to do to avoid } \\
\text { sibling jealousy }\end{array}$ & 228 & 58.5 \\
\hline Yes & 162 & 41.5 \\
\hline \multicolumn{3}{|l|}{ No } \\
\hline $\begin{array}{l}\text { The status of receiving information about } \\
\text { childrearing before }\end{array}$ & 186 & 47.7 \\
\hline Yes & 204 & 52.3 \\
\hline \multicolumn{3}{|l|}{ No } \\
\hline $\begin{array}{l}\text { The source of information regarding } \\
\text { childrearing * }(n=433)\end{array}$ & 125 & 28.9 \\
\hline
\end{tabular}




\begin{tabular}{l|c|c} 
TV/radio/internet & 117 & 27.1 \\
\hline Book/magazine & 50 & 11.5 \\
\hline Doctor & 42 & 9.7 \\
\hline Teacher & 43 & 9.9 \\
\hline Seminar/Conference/ Child development course & 56 & 12.9 \\
\hline Family/Neighbors & & \\
\hline
\end{tabular}

*More than one answer.

The mean age of the mothers and fathers were found to be $32.99 \pm 4.99$ and $36.35 \pm 5.67$ respectively. Most of the mothers were housewives (75.4\%) and primary school graduates (42.1\%). 94.6\% of them informed their children about their new sibling, and $58.5 \%$ had knowledge about avoiding sibling jealousy and $47.7 \%$ got information on childrearing mostly from television, radio and the internet. $59.5 \%$ of the mothers started to prepare the older child for the birth of the baby after the confirmation of their the pregnancy, 17.2\% in the last month of their pregnancy, $13.1 \%$ in the course of planning to get pregnant and $\% 10.3$ did not start to do so yet (Table 1 ).

Table 2. The distribution of gender and age average by number of children

\begin{tabular}{lccccc}
\hline \multicolumn{3}{l}{$\begin{array}{l}\text { Birth order of } \\
\text { the child }\end{array}$} & Girl & \multicolumn{5}{c}{ Gender } \\
\hline 1.Child & 228 & 58.5 & 162 & 41.6 & $8.51 \pm 4.49$ \\
2. Child & 119 & 53.4 & 104 & 46.6 & $7.76 \pm 4.08$ \\
3. Child & 42 & 51.9 & 39 & 48.1 & $6.21 \pm 3.53$ \\
$\geq 4$. Child & 5 & 55.6 & 4 & 44.4 & $6.66 \pm 4.21$ \\
\hline
\end{tabular}

It was determined that the first child of $58.5 \%$ of the mothers was a girl and their mean age was $8.51 \pm 4.49$ (Table 2).

Table 3. The causes of sibling jealousy according to the mothers and the practices they did to avoid it.

\begin{tabular}{lcc}
\hline Causes $(\mathbf{n}=\mathbf{3 7 1})$ & Number & $\%$ \\
\hline Fear of a decrease in the interest & 123 & 33.2 \\
Reluctant to share the parents & 99 & 26.7 \\
Reluctant to share their possessions & 68 & 18.3 \\
Fear of not being loved & 58 & 15.6 \\
Try to draw attention and jealousy towards the sibling & 23 & 6.2 \\
\hline Practices ( $\mathbf{n}=309$ ) & Number & $\%$ \\
\hline To allocate equal attention and time & 165 & 53.4 \\
To be patient and have mediatory attitude & 49 & 15.9 \\
To involve the child in the baby care & 37 & 12.0 \\
To explain correct behaviors & 29 & 9.4 \\
Not to be interested in the baby near the child & 23 & 7.4 \\
To let the child cuddle the baby & 3 & 1.0 \\
To tell the child that the baby will not take his/her toys & 2 & 0.6 \\
To behave decisively & 1 & 0.3 \\
\hline
\end{tabular}

It was noted that $71.8 \%$ of the participants pointed out that they knew the reasons for the sibling jealousy, and the causes of sibling jealousy were reported as the fear of a decrease in 
the interest (33.2\%), reluctance to share their parents (26.3\%) and their toys (18.3\%). To avoid sibling jealousy, mothers stated that they would give equal attention to their children, spend equal time with them, behave more patiently and have a mediating role (Table 3).

Table 4. The distribution of children's current jealousy behaviors and after learning that they would have a new sibling.

\begin{tabular}{|c|c|c|c|c|}
\hline \multirow[t]{2}{*}{ Jealousy behaviors } & \multicolumn{2}{|c|}{$\begin{array}{l}\text { After learning that they } \\
\text { would have a new } \\
\text { sibling }\end{array}$} & \multicolumn{2}{|c|}{ Current } \\
\hline & Number & $\%$ & Number & $\%$ \\
\hline Anxiousness & 149 & 38.2 & 87 & 22.3 \\
\hline Nervousness & 98 & 25.1 & 76 & 19.5 \\
\hline $\begin{array}{l}\text { To ask whether he/she is loved very } \\
\text { often } \\
\text { To ask for something for the baby }\end{array}$ & 78 & 20.0 & 52 & $13 \cdot 3$ \\
\hline $\begin{array}{l}\text { too, while something is bought for } \\
\text { them } \\
\text { To ask for using anything that }\end{array}$ & 74 & 19.0 & 59 & 15.1 \\
\hline belongs to the baby & 65 & 16.7 & 61 & 15.6 \\
\hline Aggressive behaviors & 57 & 14.6 & 49 & 12.6 \\
\hline To become introverted & 50 & 12.8 & 33 & 16.8 \\
\hline $\begin{array}{l}\text { To exhibit different behaviors } \\
\text { towards the foreigners who come }\end{array}$ & & & & \\
\hline $\begin{array}{l}\text { home (such as excessive love, } \\
\text { aggression, not talking) }\end{array}$ & 42 & 10.8 & 37 & 9.5 \\
\hline $\begin{array}{l}\text { Not to share their toys with the } \\
\text { baby }\end{array}$ & 38 & 9.7 & 59 & 15.1 \\
\hline \multicolumn{5}{|l|}{ To behave excessively spoiled } \\
\hline & 37 & 9.5 & 35 & 9.0 \\
\hline $\begin{array}{l}\text { To be willing to participate in baby } \\
\text { care (such as feeding ) }\end{array}$ & 36 & 9.2 & 40 & 10.3 \\
\hline $\begin{array}{l}\text { To think that the baby is treated } \\
\text { differently }\end{array}$ & & & & \\
\hline & 32 & 8.2 & 54 & 13.8 \\
\hline Decrease in eating habits & 30 & 7.7 & 20 & 5.1 \\
\hline To bite nails & 28 & 7.2 & 35 & 9.0 \\
\hline To stutter and speak like babies & 28 & 7.2 & 16 & 4.1 \\
\hline Change in sleeping hours & 28 & 7.2 & 19 & 4.9 \\
\hline To ask for breastfeeding & 27 & 6.9 & 25 & 6.4 \\
\hline $\begin{array}{l}\text { Bedwetting } \\
\text { To be harmful to their sibling }\end{array}$ & 24 & 3.3 & 13 & 3.3 \\
\hline (biting) & 24 & 6.2 & 30 & 7.7 \\
\hline $\begin{array}{l}\text { Unable to focus on doing } \\
\text { something }\end{array}$ & 22 & 5.6 & 24 & 6.2 \\
\hline $\begin{array}{l}\text { Excessive behaviors while } \\
\text { caressing the baby (such as }\end{array}$ & & & & \\
\hline $\begin{array}{l}\text { squeezing the baby hard, dropping } \\
\text { accidentally...) }\end{array}$ & 21 & 5.4 & 39 & 10.0 \\
\hline Clumsiness & 19 & $4 \cdot 9$ & 23 & 5.9 \\
\hline To lose weight & 18 & 4.6 & 17 & 4.4 \\
\hline
\end{tabular}


To be reluctant to go to 18 kindergarten or school

Finger sucking

Increase in eating habits

To get complaints about their

behaviors (neighbor, teacher ...)

To defecate their pants

To gain weight
18

13

12

11

7

5
4.6

3.3

3.1

2.8

1.8

1.3
3.6

3.6

92.3

12

3.1

1.3

2.8

When the jealousy attitudes of the children after learning that they would have a new sibling were examined, anxiousness, nervousness, and their questions regarding whether their parents loved them were found among their major reactions. The jealousy behaviors they exhibited after the birth of the baby were anxiousness, nervousness, asking for something also for the baby while something is bought for them and reluctance to share their toys with the new sibling (Table 4)

Table 5. The distribution of jealousy behaviors of the children after learning they would have a new sibling according to socio-demographic characteristics of the mothers

\begin{tabular}{|c|c|c|c|c|c|}
\hline & \multicolumn{4}{|c|}{$\begin{array}{l}\text { Whether the children have jealousy behaviors after } \\
\text { learning they would have a new sibling }\end{array}$} & \multirow{3}{*}{$\begin{array}{c}\text { Statistics } \\
\mathrm{X}^{2} ; \mathrm{p}\end{array}$} \\
\hline & \multicolumn{2}{|c|}{ Yes } & \multicolumn{2}{|c|}{ No } & \\
\hline & Number & $\%$ & Number & $\%$ & \\
\hline \multicolumn{5}{|c|}{ Age group of the mother } & \\
\hline$\leq 35$ years old & 95 & 80.5 & 177 & 65.1 & \multirow{2}{*}{$\begin{aligned} X^{2} & =9.291 \\
p & =0.00\end{aligned}$} \\
\hline$>35$ years old & 23 & 19.5 & 95 & 34.9 & \\
\hline \multicolumn{5}{|c|}{ Educational status of the mothers } & \multirow{5}{*}{$\begin{array}{c}X^{2}=8.874 \\
p=0.03\end{array}$} \\
\hline Primary school & 38 & 32.2 & 126 & 46.3 & \\
\hline $\begin{array}{l}\text { Secondary } \\
\text { school }\end{array}$ & 17 & 14.4 & 40 & 14.7 & \\
\hline High school & 42 & 35.6 & 78 & 28.7 & \\
\hline University & 21 & 17.8 & 28 & 10.3 & \\
\hline \multicolumn{5}{|c|}{ The birth order of the child } & \multirow{4}{*}{$\begin{array}{l}X^{2}=1.372 \\
p=0.504\end{array}$} \\
\hline First child & 50 & 42.4 & 118 & 43.4 & \\
\hline 2.child & 47 & 39.8 & 94 & 34.6 & \\
\hline$\geq 3$. child & 21 & 17.8 & 60 & 22.0 & \\
\hline \multicolumn{5}{|c|}{ The time when the mother started to prepare the child for the new sibling } & \multirow{5}{*}{$\begin{aligned} X^{2} & =8.466 \\
p & =0.03\end{aligned}$} \\
\hline $\begin{array}{l}\text { After the } \\
\text { confirmation of } \\
\text { their } \\
\text { pregnancy }\end{array}$ & 67 & 56.8 & 165 & 60.7 & \\
\hline $\begin{array}{l}\text { In the last } \\
\text { months of the } \\
\text { pregnancy }\end{array}$ & 16 & 13.6 & 51 & 18.8 & \\
\hline $\begin{array}{l}\text { In the course } \\
\text { of planning the } \\
\text { pregnancy }\end{array}$ & 24 & 20.3 & 27 & 9.9 & \\
\hline Not yet & 11 & 9.3 & 29 & 10.7 & \\
\hline
\end{tabular}


The mothers in the age group of $\leq 35$ stated that their children exhibited more sibling jealousy behaviors than those of the other age groups. Sibling jealousy was reported to be seen more frequently in the children of the high school graduates and in the first children of the family (Table 5).

Table 6. Comparison of current jealousy behaviors scores of children and those after learning that they would have a new sibling

\begin{tabular}{lccccc}
\hline Change & $\mathrm{n}$ & $\overline{\mathbf{X}}$ & $\mathrm{S} . \mathrm{S}$. & $\mathrm{t}$ & $\mathrm{p}^{*}$ \\
\hline $\begin{array}{l}\text { After learning they would have } \mathrm{a} \\
\text { sibling }\end{array}$ & 193 & 55.72 & 4.65 & 5.485 & 0.000 \\
$\begin{array}{l}\text { Current } \\
\text { Curen }\end{array}$ & 193 & 53.13 & 5.10 & & \\
\hline
\end{tabular}

*significance

The mean scores of the current jealousy behaviors of the children in the study $(53.13 \pm 5.10)$ were found to be significantly lower than those $(55.72 \pm 4.65)$ after learning they would have a new sibling $(t=5.485, p=0.00)$ (Table 6$)$.

This descriptive study was conducted to assess the knowledge, attitudes and practices of the expectant mothers towards sibling jealousy. The study findings showed us that sibling jealousy is a common problem that almost every parent experiences. In a survey with 622 students aged 12-17 years, the distribution of the problems experienced by the students with their families was examined and the ratio of sibling jealousy was found to be as $13.8 \%$ (Yilmazeli and Gunay, 2012). In another study conducted with a total of 1342 sophomore high school students from four different schools, it was found that $58 \%$ of the students did not have any problems with their families, $16.8 \%$ of them had problems with more than one person in their families and $15.7 \%$ had problems related to sibling jealousy (Ertem and Yazici, 2006). Fidan (2011) examined the distribution of psychological symptoms of the children and adolescents admitted to the polyclinic of child and adolescent mental health diseases on the first visit, and reported that 20 out of 632 people (3.2\%) had sibling jealousy. Gorker, Korkmazlar, Durukan and Aydogdu (2004) argued that among 229 symptoms of 1079 adolescents between the ages of 12-18, the most common ones were nervousness, school failure, nail-biting, distress, disagreement with peers and sibling jealousy. $20 \%$ of teachers who participated in a qualitative study thought that their students needed guidance on sibling jealousy (Kesici, 2007).

Our study demonstrated that $94.6 \%$ of mothers, almost all of them, informed their older child about the pregnancy, most of them (58.5\%) had information to avoid jealousy among the siblings but half of them (52.3\%) did not get any information about childrearing before, and those who got this kind of information received it mostly from television and the internet. $\mathrm{Er}$ and Saricam (2016) found that the parents did not have enough information about sibling jealousy. Our research is different from this work in this respect. However, it was seen that the jealousy among the siblings started before the baby was born and continued after the birth. Ceylan, Kahraman and Ulker (2016) suggested that sibling jealousy is the most challenging situation that mothers face in early childhood.

When we examined the causes of sibling jealousy according to the mothers, we found that the children were afraid of the possibility of decrease in interest and they were reluctant to share their parents and toys. A large part of the mothers said that in order to avoid jealousy they would spend equal time with their children and behave them equally. 
The importance of the parents' behaviors cannot be denied in the sibling jealousy. In one study, it was suggested that the feeling of jealousy towards the sibling was higher in those who were exposed to maternal and paternal controls as well as less maternal love and father passion (Rauer and Volling, 2007). In another study, children showed more distress and destructive behavior in response to baby-father interactions rather than baby-mother interactions (Volling et al., 2014). In this case, the child may think that baby-mother relationship is inevitable, but baby-father relationship is a loss. (Volling et al., 2014). According to the findings obtained in another study, twin siblings were found to be reactive only in the case of loss of interest or decrease in mother's interest, and that they did not exhibit jealousy behaviors in terms of harmony and competition with the other siblings (Şipal, et al.,, 2012).

Sibling jealousy seems to be relatively less in siblings in the small age range (aged 3 years or less) and it is stated that birth order does not play an important role on jealousy. Our study revealed that sibling jealousy was more common in siblings in the wide age range. Since the mother and the father devote much of their time to the little baby who is in need of care, the older child can be jealous, thinking that his/her parents no longer care about him/her $(\mathrm{Oz}$, 2000). In this study, it was also seen that the feelings that the children exhibited after learning that they would have a new sibling and after the baby came home were mostly anxiousness, nervousness and constantly asking their parents whether they liked them. Similarly, Yegin (2005) found that the most common jealousy behaviors were mostly asking for using something that belonged to his/her sibling, not wanting his/her parents to buy something new for the sibling while they were buying something himself/herself, telling that his/her sibling is treated differently, and asking his/her parents whether they loved him/her. In the same study, it was found out the current jealousy behaviors of the children were significantly higher than those at the time after learning they would have a sibling. However, our study findings were just the opposite in this respect; the current jealousy behaviors of the children were found to be significantly lower than before.

In our study, it was observed that the sibling jealousy was higher in girls (Table 2). As regards to gender, while some studies reported that siblings of the same sex are more likely to be jealous, some others suggested that gender has no significant effect on sibling jealousy (Thompson, 2004). Similarly, Derman and Basal (2013) examined the relationship between behavior problems observed in pre-school children and their parents' attitudes and found that jealousy is more common in girls than in boys (Derman and Basal, 2013).

The age and educational level of the mothers are among the factors affecting the sibling jealousy, and it is thought that educated parents may be more sensitive to the development of their children. In our study, it was observed that the sibling jealousy was higher in the children of the mothers aged 35 and below (Table 5). According to the education level, sibling jealousy was higher in the children of high school graduated mothers and there was a statistically significant difference between the mother age range, educational status and sibling jealousy in children. That more sibling jealousy was observed in the children of high school graduate mothers is thought to be due to the fact that most of the parents who were in the age group of 35 years and under were high school graduates. Contrary to our study results, in Yigen's (2005) study, it was seen that there was no significant difference between the jealousy behaviors of the children and the education level of the mothers.

The study found that sibling jealousy in the children of the mothers who started to prepare their children about the birth of a baby after the confirmation of the pregnancy was found to 
be more than the children of the mothers who explained it before planning the pregnancy, in the last months of pregnancy and who did not explain yet and there was a statistically significant difference between the groups $(X=8.466 ; p=0.03)$. Donat Bacioglu (2017) stated that as the mother's stomach began to evolve, the fact that her child began to love the baby and starts to communicate with the baby standing near her could smooth the feeling of jealousy towards the baby.

\section{CONCLUSION}

In the study, sibling jealousy behaviors of the children after the baby came home were found to be significantly lower than those after learning they would have a new sibling. There was a significant difference between the jealousy behaviors of the children and the age group and education level of the parents. Girls were found to have more sibling jealousy behaviors than boys. When the jealousy attitudes of the children after learning that they would have a sibling were examined, anxiousness, nervousness, and their questions regarding whether their parents loved them were found among their major reactions.

One of the important roles of the child health nurse is to protect the health of the child in prenatal and postnatal periods. The participation of a new individual to the family can cause stress and change in the family roles and sometimes parents may have difficulty and be worried about sibling jealousy. Psychological problems such as finger sucking, bedwetting, speaking like babies can arise in the future lives of the children whose jealousy feelings cannot be improved. For this reason, the counseling and guidance of pediatric nurses for the parents about the right approaches to their children especially regarding sibling jealousy will be helpful in preventing the problems that families may experience.

\section{REFERENCES}

Alper, Z. (2002). Kardesler arasi iliskiler ve psikolojik sonucları. Anadolu Universitesi Acik ogretim Fakultesi On lisans programi Aile Psikolojisi ve Egitimi Kitabi, Eskisehir: Anadolu Universitesi Acik ogretim Fakultesi Yayinevi.

Bauminger, N., et al. (2008). Jealousy and emotional responsiveness in young children with ASD, Cognition \& Emotion, 22(4), 595-619.

Ceylan, S. Kahraman, O. G. \& Ulker, P. (2016). Annelerin erken cocukluk donemine bakis acisi. Insan ve Toplum Bilimleri Arastırmaları Dergisi, 5(5), 1333-1356.

Derman, M. T. \& Basal, H. A. (2013). Okuloncesi cocuklarinda gozlenen davranis problemleri ile ailelerinin anne-baba tutumlari arasindaki iliski. Amasya Universitesi Egitim Fakultesi Dergisi, 2(1), 115-144.

Donat Bacioglu, S. (2017). 0-6 yas bebeklik ve erken cocukluk doneminde uyum ve davranis problemleri. Savi Cakar, F. (Ed.), Yasam donemi ve uyum sorunlari (s.119-161). Anakara: Pegem Akademi.

Er, H. \& Saricam, H. (2016). Ebeveynlerin Kardes Kiskancligi lle llgili Goruslerinin Incelenmesi ve Cozum Onerileri. Besinci Egitim Arastırmaları Kongresi'nde Bildiri olarak sunulmustur.

Ertem, U. \& Yazici, S. (2006). Psiko-sosyal sorunlar ve depresyon. Aile ve Toplum, 3(9), 7-12.

Fidan, T. Y. (2011). Bir Cocuk- Ergen Ruh Sagligi ve Hastaliklari Poliklinigine basvuran cocuk ve ergenlerin ruhsal belirtileri ve risk faktorlerinin degerlendirilmesi. Konuralp Tıp Dergisi, 3(1), $1-8$. 
Fraenkel, J. et al. (2006). How to design and evaluate research in education. New York: McGrawHill Education.

Gorker I., et al. (2004). Cocuk ve Ergen Psikiyatri Klinigine Basvuran Ergenlerde Belirti ve Tani Dagilimi. 14. Ulusal Cocuk ve Ergen Ruh Sagligi ve Hastaliklari Kongresi'nde Poster Bildiri olarak sunulmustur.

Gumus, Y. S. (2016). Kardes Kiskancligi, Yeni Bir Bebek ve Kiskanclik, Kardes Kavgasini, Kiskancligini Nasil Onleyebilirsiniz. http://www.pedagogsevilyavuz.com/detay-icerikpedagog-sevil-yavuz-173-makaleler-kardes-kiskancligi-yeni-bir-bebek-ve-kiskanclikkardes-kavgasini-kiskancligini-nasil-onleyebilirsiniz.html adresinden 11.04.2018 tarihinde alinmistir.

Kesici, S. (2007). Sube rehber ogretmenlerinin goruslerine gore 6., 7. Ve 8. sinif ogrencilerinin rehberlik ve danisma ihtiyaclari, Selcuk Universitesi Sosyal Bilimler Enstitusu Dergisi, $17,365-383$.

Kilicaslan, A. (2001). Aile fonksiyonlarının ve algilanan farklilasmis anne-baba yaklasiminin kardes iliskileri uzerindeki etkisi. Yuksek Lisans Tezi. Istanbul Universitesi, Istanbul.

Miller, A. L., Volling, B. L. \& McElvain, N. L. (2000). Sibling Jealousy in a Triadic Context with Mothers and Fathers, Social Development. 9(4), 434-457.

Noller, P. (2005). Sibling relationships in adolescence: Learning and growing together. Personal Relationships, 12: 1-22.

Oz, I. (2000). Kardes kiskancligi. Coluk Cocuk Aylık Anne-Baba Egitimci Dergisi. S:8. 15., 1-4.

Ozyurek, A. (2015). Cocuk ve aile ici iliskileri. Aydogan, Y.ve Gultekin Akduman, G.(Ed.), Cocuk ruh sagligi (s. 73-98). Ankara: Egiten

Pike, A., Coldwell, J. \& Dunn, J. F. (2005). Sibling relationships in early/middle childhood: Links eith individual adjustment, Journel of Family Psychology, 19(4), 523-532.

Rauer, A. J. \& Volling, B. L. (2007). Differential Parenting And Sibling Jealousy: Developmental Correlates Of Young Adults' Romantic Relationships, Pers Relatsh, 14(4), 495-511.

Sipal, R. F. ve Yegengil, C. \& Toka, N. (2012). Okul Oncesi Donemde Aralarinda Yas Farki Olan ve Ikiz Kardesler Arasindaki Kiskancligin Karsilastirmali Olarak Incelenmesi, Egitim ve Insani Bilimler Dergisi: Teori ve Uygulama, 3(5), 55-68.

Thampson, J. A. \& Halberstadt, A.G. (2008). Children'sAccounts of Sibling Jealousy and Their Implicit Theories about Relationships, Social Development, 1-24.

Thompson, J. A. (2004). Implicit Beliefs about Relationships Impact Sibling Jealousy Experience.

Volling, B. L., et al. (2014). Children's Responses to Mother-Infant and Father-Infant Interaction with a Baby Sibling: Jealousy or Joy? J Fam Psychol. 28(5), 634-644.

Yavuzer H.(2010). Cocuklarda kardes kiskancligi. Okulumu Seviyorum Dergisi. 82, 2-5.

Yavuzer, H. (2007). Çocuk Psikolojisi, 27. Baskı, Remzi Kitabevi, İstanbul s:136-137.

Yigen, E. (2005). Zonguldak II Merkezinde Yuvaya Giden 3-6 Yas Grubu Cocuklarda Kardes Kiskancliginin Degerlendirilmesi. Yayimlanmis Yuksek Lisans Tezi. Zonguldak: Karaelmas Universitesi. Cocuk Sagligi ve Hemsireligi Anabilim Dali.

Yildirim, A. ve Simsek, H. (2016). Sosyal Bilimlerde Nitel Araştırma Yontemleri. Ankara: Seckin.

Yilmazeli, G. ve Gunay, O. (2012). Corum ili Kargi ilcesinde ogrenim goren 12-17 yas arasindaki ogrencilerde ozsaygi ve depresyon. Saglık Bilimleri Dergisi, 21(1), 20-29.

Yorukoglu, A. (2006). Cocuk Ruh Sagligi. Istanbul: Ozgur Yayinlari. 


\section{Biographical notes:}

Asst. Prof. Dr. ilknur KAHRiMAN, graduated from Hacettepe University Nursing High School in 1991 and then completed a master's degree program in child health and disease nursing and public health departments. In 2012, she completed doctoral program in child health and diseases nursing. Ilknur Kahriman, is the head of the department of child health and illness nursing since 2013, as well as the presidency of child development department in Karadeniz Technical University. Kahriman, has a broad background in clinical practice and education. She teaches courses in neonatal resuscitation and neonatal intensive care nursing. Kahriman's research focuses on newborns, adolescents and children with mental disabilities and their families. She has publications in many international and national journals in these fields.

Asst. Prof. Dr. Mehmet KANAK completed his bachelor's degree on preschool education at the Cumhuriyet University 2007 and master degree on preschool education at the İnönönü Unuversity 2011 and PhD degree on child development and education at the Gazi University 2015. The authors' work areas are child neglect and abuse, children's rights, technology dependency and development. After two years of teaching experience of the authors in the ministry of education as a lecturer at the Hitit university in 2009, he began his academic studies. He started to work as a lecturer at Cumhuriyet University in 2013 and has been working as an assistant professor at the same university since 2015. He has studies in child abuse and neglect, preschool education, child development and teacher training. 